mammals. The joys of the place and what can be seen are described in "My Tropic Air Castle".

The love of birds brought Theodore Roosevelt and Chapman together, and through Roosevelt he was invited by Lord Grey to the British Embassy to talk birds. Later, during visits to Great Britain, he was taken by Lord Grey to see birds in the New Forest and along the banks of the Itchin, and a few years after he paid a visit to Fallodon which is vividly described in the "Autobiography of a Bird Lover".

Chapman was an ardent protectionist and for many years edited Bird Lore, the magazine of the Audubon Societies. In 1893 he published a useful "Handbook of Birds of Eastern North America", a revised edition of which appeared in 1912.

To Chapman the American Museum owes the development of the habitat groups for which that Museum is so famous.

In 1898 Chapman married Miss Embury, and the marriage was an ideally happy one, his wife developing as keen an interest in birds as her husband and often accompanying him in the field. N. B. Kinnear.

\section{Dr. H. E. Durham}

By the death at Cambridge, on October 5, of Dr. Herbert Edward Durham both bacteriology and botany lose a distinguished discoverer. Durham was born in London in 1866. He was the son of A. E. Durham, senior surgeon to Guy's Hospital and a grandson of William Ellis, the economist. Educated at University College School and King's College, Cambridge, Durham took first class honours in Parts I and II of the Natural Sciences Tripos at Cambridge in 1890, his medical qualification in 1892 and his F.R.C.S. in 1894. In 1894 he was appointed to a Gull Research Studentship and went to Vienna to work in Gruber's hygiene laboratory. There he and Gruber first directed attention in January 1896 to the diagnostic value of the agglutination of pathogenic organisms by the sera of animals immunized against them. Later in 1896 this test was applied by Widal for the diagnosis of typhoid fever. The reaction was known for a time as the Gruber-Durham reaction and later as the Widal reaction.

In 1896 Durham was appointed a member of a Royal Society committee upon diseases transmitted by tsetse flies. In 1897, while holding a Grocers' Scholarship and working at Cambridge, Durham described the Durham tube, a small inverted testtube placed in bacteriological media for the collection of the gas produced by fermentative organisms. In 1900 he headed the expedition sent by the Liverpool School of Tropical Medicine to Brazil to study yellow fever. Durham contracted the disease, but lived to lead, during 1901-3, the expedition sent by the London School of Tropical Medicine to Christmas Island and Malaya for the study of beriberi. From Malaya, Durham brought home samples of Derris elliptica and appears to have been the first to recognize the insecticidal properties of this plant.

In 1905 Durham was appointed supervisor of the laboratories of Messrs. H. P. Bulmer and Co., of Hereford, where he worked for thirty years upon problems of fermentation and apple culture in relation to cider production. In 1909 he took his Sc.D., Cambridge, and in 1935 retired to Cambridge, where he cultivated, in his garden there, many culinary plants and herbs which are rare in Great Britain. Many of these he had himself introduced, and several
Cambridge gardens still chorish those which ho gavo to their owners.

A retiring man who could be a charming and humorous companion, Durham acquired a wide culture and was always ready to give of his rich store of experience to his many correspondents and friends. He sent many valuable contributions to the "Dictionary of Gastronomy". Responsible for much original work, and also for much stimulation of others, he scattered his knowledge in private communications and did not always obtain full credit for his discoveries. Not least among his later activities were his hobbies of photography and lathe-work. While his bacteriological work is well known, his contributions to botany, and especially perhaps to apple culture and problems of fermentation, merit wider recognition. The sympathy of everyone will go out to Mrs. Durham, who survives him, and to his brother, Colonel F. R. Durham, secretary of the Royal Horticultural Society.

G. LAPAGE.

\section{Prof. C. E. Wright}

THE death of Prof. C. E. Wright, professor of gunnery and mathematics at the Military College of Science, Woolwich, occurred on October 30, 1945.

Charles Edward Wright was born on January 31, 1886. He studied mathematics at King's College, London, between 1903 and 1906, where he was awarded the Clothworkers' and Sambrooke Exhibitions and a Drew Gold Medal. After graduating he was appointed tutor at University Correspondence Gollege, Cambridge. During the War of 1914 18 he served with the Royal Engineers and was, for a short time, at the Research Department, Woolwich. $\mathrm{He}_{\Theta}$ obtained the degree of M.Sc. by examination at Queen Mary College, London, in 1921.

In 1919, Wright took up the appointment of senior lecturer at the Military College of Science, Woolwich, where he spent the greater part of his career and where he was appointed professor shortly after the retirement of Prof. H. C. Plummer in 1940. Wright was wholeheartedly devoted to the instruction of army officers to fit them for technical staff appointments. The many students who have worked under him have proved their value during the recent War, where their services have proved indispensable in the development and production of weapons to meet the needs of the soldier in the field. Apart from his professional duties, Wright was actively engaged in voluntary war work, but alas, his zeal was greater than his strength.

He was an able mathematician and, in addition to his instructional duties and the preparation of Service text-books on ballistics, he found time to write several papers and notes published in the Philosophical Magazine and educational journals. The elegance exhibited in some of his mathematical work is most attractive. He was of a cheerful disposition and was popular with students and staff alike.

C. J. Tranter.

WE regret to announce the following deaths :

Dr. E. F. Armstrong, F.R.S., on December 14, aged sixty-seven.

Mr. A. Lucas, O.B.E., sometime chemist to the Egyptian Department of Antiquities, on December 9, aged seventy-six.

Mr. F. Milsom, for many years the official referee for Hepatics for the British Bryological Society, on December 5 . 